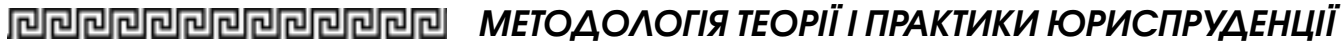

УДК 340.12:165.191

DOI https: / / doi.org/10.32837/yuv.v0i2.1698

\section{Ю. Тіщенко,}

кандидат юридичних наук, доцент, доцент кафедри загальнотеоретичної юриспруденції

Національний університет «Одеська юридична академія»

\section{ПРАВОВИЙ МІФ У СТРУКТУРІ ПРАВОВОЇ РЕАЛЬНОСТІ}

Розгляд правової міфології з позицій філософії права передбачає виявлення ii місця у структурі правової реальності як особливої сфери людського буття. Проте вказана проблема недостатньо досліджена в сучасній літературі. До того ж можна стверджувати, що правовий міф існує в таких ключових складниках правової реальності, як правосвідомість, джерела (витоки) права, позитивне право, правова поведінка.

Мети статті - визначити та окреслити місце й роль правових міфів у структурі правової реальності.

Визнання існування у праві міфологічних конструкцій безпосередньо пов'язане зі становленням некласичного й постнекласичного способів осягнення правової реальності. Такі моделі дають можливість пізнання не тільки раціональних, логічних витоків права, але й нераціональних, чуттєвих його компонентів. Їх поєднання стає суттєвою ознакою сучасної методології юриспруденціі.

У правовій реальності правові міфи існують в особливих форма, трансформуючись у правосвідомості, знаходячи своє відображення у джерелах права, правових нормативах та у правовій поведінці.

Ю.М. Оборотов розглядає правову реальність як особливий автономний світ права зі своӥми тенденціями, логікою функціонування та розвитку, що охоплює самостійні різновиди буття права: нормативну (інституційну) реальність, реальність правосвідомості, реальність правової поведінки [11, c. 276].

(C) Ю. Тіщенко, 2020
У Великій українській юридичній енциклопедії визначається, що правова реальність - це поняття, яке вживається для позначення особливого автономного світу права зі своїми законами й логікою функціонування та розвитку, зі своїми «несучими конструкціями» i способом їх поєднання в одне ціле. Воно покликане показати, що право не є певною річчю, на яку можна вказати: ось це і є право, але натомість являє собою багатогранний динамічний світ правових смислів [4, с. 642].

Правова реальність, на думку C.I. Максимова, складається 3 таких рівнів, тобто форм буття права: світу ідей (ідея права); світу знакових форм (правові норми й закони); світу взаємодії між соціальними суб'єктами (правове життя) [8, с. 75].

Щоб простежити структурно-функціональну зумовленість буття правових міфів у правовій реальності, необхідно визначити ї статус у контексті різних підходів до іiі розуміння. На думку Г.І. Іконникової і В.П. Ляшенко, є такі підходи до розуміння правової реальності: діалектико-матеріалістичний, феноменологічний, системний i сферний [7, с. 143-147].

Із позицій діалектико-матеріалістичного підходу, який домінував у радянській юриспруденції, правова реальність - це результат відображальної функції правосвідомості, нашого сприйняття права як дієвого механізму регулювання поведінки людей. За такого підходу правова реальність - це елемент соціальної реальності, котрий базується на економіці й розвивається 
за законами діалектики. Незважаючи на те, що такий підхід отримав свого часу широке визнання, сьогодні його складно назвати поширеним та використовуваним, оскільки, по-перше, він ставить правову реальність і жорстку залежність від економічної реальності, по-друге, відмовляє правовій реальності в об'єктивному існуванні поза індивідуальною та колективною свідомістю i, по-третє, ігнорує системність зв'язків між правом як об'єктивною системою і його практичним вираженням.

Феноменологічний підхід до розуміння правової реальності випливає із тлумачення права і правових явищ як феноменів, які можуть осягатись не тільки раціонально, але й чуттєво. Під кутом зору феноменологічного підходу правова реальність постає як екзистенція: навколишній світ кожної окремої людини, присутній у житті кожного суб'єкта безпосередньо, а не опосередковано через правові норми або інші об’єктно-орієнтовані елементи, які є зовнішніми щодо суб'єкта. Феноменологічний підхід сьогодні $€$ досить популярним, оскільки дозволяє застосовувати у праві екзистенціальну методологію, що відповідає завданням та цілям юридичної антропології.

Сферний підхід до розуміння правової реальності в останні роки стрімко розвивається, оскільки пропонує розглядати право з позицій його змістовного аналізу. За допомогою сферного підходу правова реальність постає як цілісність різнопланових сфер, передовсім - сфери норм та сфери цінностей, які в поєднанні утворюють правову сфреру. Інша можлива інтерпретація цього підходу - використання концептів практичної сфери, наукової сфери, філософської сфери в осягненні права.

Ще одним поширеним варіантом розгляду правової реальності є системний підхід, який полягає у виявленні горизонтальних і вертикальних зв'язків різних пластів права як комплексного явища. Під кутом зору системного підходу, правова реальність охоплює такі підсистеми:
- інтелектуально-психологічна, що функціонально забезпечує формування індивідуальної правосвідомості. На рівні правосвідомості $є$ система правових понять, аксіом і нормативних установок, а також почуттів, емоцій, переживань, які трансформуються й розвиваються залежно від конкретної правової ситуації;

- нормативно-регулятивна, котра формує реальність як систему правових нормативів, об'єктивується в людській діяльності, правових відносинах, системі позитивного права, джерелах права;

- соціально-результативна, яка фіксує повноту включення суб'єктів у право, рівень сприйняття його компонентів і ступінь інтеграції правової сфери;

- організаційно-діяльнісна, що охоплює всі типи правової активності суб'єктів правової сфери: правотворчу, правозастосовчу, правоохоронну та інші.

Правові міфи існують у кожній з указаних сфер і зрізів правової реальності, оскільки саме в цьому проявляється система їх властивостей. Властивості правового міфу - найбільш суттєві характеристики, які відрізняють його від інших правових явищ і властиві взагалі міфу як явищу культури.

Розгляд правового міфу у правовій реальності крізь призму його властивостей неминуче виводить на проблему існування міфу у правовій свідомості первинного складника правової реальності і, як уявляється, у цій сфері існування різних міфологічних структур домінує, порівняно з іншими пластами правової реальності.

Правосвідомість традиційно розглядається в юридичній літературі як одна 3 основних форм буття права (поряд із правовою нормою і правовими відносинами). Це, безсумнівно, не тільки підвищує статус цього феномена в системі юридичних категорій, а й вимагає глибокого аналізу правосвідомості з погляду відображення в ній правових міфів.

Особливістю феноменологічного сприйняття правових міфів $€$ те, що 


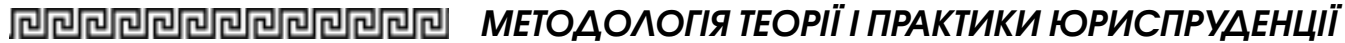

вони одночасно перебувають у контексті раціонального й чуттєвого, тобто одночасно у двох площинах сприйняття права, що, зі свого боку, дозволяє міфу відображатись у різноманітних структурних елементах правосвідомості.

Проблемі вивчення соціального феномена правосвідомості присвятили свої праці видатні теоретики й філософи права минулого й сучасності, проте необхідно зазначити, що у правовій науці домінує так званий раціональний підхід до правової свідомості. Так, серед особливостей правосвідомості як досить складного, багатоаспектного явища виокремлюють думку, що правосвідомість означає сконструйовану суб'єктом (індивідом або групою, спільнотою) картину світу, в якій суб'єкт бачить можливості реалізувати свої життєві цілі через діяльність правових інститутів [4, с. 645]; правосвідомість характеризує всю сукупність духовних утворень, що визначають здатність людини до існування у правовому просторі, ї вміння слідувати нормам права, нести відповідальність за реалізацію своїх прав і свобод [17, с. 12]; ключовим пунктом правосвідомості є усвідомлення людьми цінності права й одночасно уявлення про справжнє право, про те, наскільки воно відповідає вимогам розуму і справедливості, правовим цінностям та ідеалам [1, с. 111].

Феномен правосвідомості ніяк не може бути обмежений одним тільки раціональним компонентом, адже процеси правоосмислення нерозривно пов'язані 3 низкою позараціональних факторів: волею, інтуїцією, емоціями, смаками, віруваннями тощо, які звичайно не поглинаються раціонально-логічними структурами розуму, проте істотно впливають на формування та реалізацію правових цінностей та ідей [15, с. 799].

Таким чином, сучасним дослідженням природи, структури, функціонування та динаміки правосвідомості 3 позиції раціоналістичної парадигми опонують позараціоналістичні підходи до іï вивчення. Серед них особливо виділяються ті, які пов'язані з постмодерністською орієнтацією в науці. Вони відверто налаштовані проти засилля логоцентризму, оскільки принцип-закон тотожності, на якому побудована вся класична логіка, що є основою логічної побудови права, позбавлений, згідно 3 розглянутою концепцією, адекватності реальним формам буття будь-якого тексту, зокрема текстовим формам фіксації правових норм. Під цим кутом зору логічна несамототожність тексту мотивується передовсім неоднозначністю його змістовно-смислових перетинів 3 іншими текстами. Як уважає Ж. Дерріда, «живого теперішнього як такого немає, минуле залишає в ньому відбиток, а майбутнє - начерк своїх обрисів. Отже, теперішнє не дорівнює саме собі, не збігається із самим собою. Воно позначено відмінністю. Текст - це саме втілення принципу гетерономності за відсутності єдиного спрямовуючого принципу» [5, с. 460].

Відповідно, правове смислотворення спрямовується не логікою буття або самого тексту, а інтуїтивною реконструкцією й непередбачуваною реінтерпретацією мовно-текстових форм правовираження. Ця оригінальна думка виводить на необхідність делогізації правової свідомості, позбавлення iii раціонального центру. Як стверджував Ж. Дерріда, центр - це не завжди об'єктивна властивість структури, а частіше результат внутрішнього переконання суб'єкта, результат нав'язування сенсу, який насправді може бути зовсім іншим. Принцип центрації, на думку філософа, пронизує всі сфери життєдіяльності сучасної людини: у філософії і психології він призводить до раціоцентризму, який утверджує пріоритет дискурсивно-логічної свідомості над іншими їі формами; в культурології - до європоцентризму, який перетворює європейську соціальну практику й тип мислення у критерій для аналізу інших форм культури; в істоpiï - до футуроцентризму, який визначає історичне сьогодення й майбутнє як завжди краще й більш прогресивне, 
ніж минуле [6, с. 8-9]. Можна продовжити цю думку й перенести іï у площину буття права, оскільки принцип центрації в юриспруденції призводить до нормоцентризму, який звеличує нормативний складник права, нерідко затьмарюючи всі інші його структурні складники, такі, як цінності, суб’єкт і ситуація.

Перебування правових міфів одночасно й у сфері правової ідеології, й у сфері правової психології свідчить про те, що вони є сполучними елементами, які пронизують усю правосвідомість, але відтворюють нераціональне, образне, чуттєве, що відображує сутнісну основу міфу, натомість раціоналізація його сприйняття є завжди вторинною.

У повсякденній правосвідомості довго культивувався й побутує досі міф про ідеального правителя, абсолютно справедливого, котрий ідеально розуміє почуття і сподівання народу. Своєрідна модифікація цього міфу, котра більше має політичний зміст, - міф про «тверду руку». Однак якщо міф про «тверду руку» швидше пов'язаний із засобами управління, із прагненням до підпорядкування, патерналізму, то міф про ідеального правителя наділений більш глибоким змістом.

Як пояснюють деякі дослідники, міф про ідеального правителя виражений, зокрема, в образі короля Артура, нерозривно пов'язаний зі становленням правової свідомості раннього Середньовіччя: диференціація політичного і правового, що остаточно сталась лише в Новий час, у кельтській міфології усвідомлювалась як розмежування держави й особистості правителя.

Міфи нерідко властиві не тільки повсякденній, а і професійній правосвідомості.

Один із яскравих прикладів такого міфу, який в Україні набув особливого поширення, - це міф про те, що зміни в законодавстві здатні автоматично вирішити комплексні проблеми у правовому житті. Такий міф отримує своє втілення в гіперактивній законодавчій діяльності, коли законодавство змінюється зі швидкістю, невластивою для нормального розвитку правової системи $[10$, с. 96$]$.

Інший показовий приклад міфу у професійної правосвідомості - уявлення про те, що встановлення більш суворих покарань веде до зниження рівня злочинності. Однак у правовому регулюванні між правовою нормою і врегульованою нею поведінкою знаходиться цілий пласт інститутів, відносин, цінностей та антицінностей, які визначають дієвість або недієвість цієї норми. Незважаючи на те, що історія права демонструє хибність такого підходу, він усе ж $є$ розповсюдженим серед юристів.

Міфи правосвідомості - як повсякденної, так і професійної - стають ідеологічними джерелами сучасного права, отримуючи своє вираження в законодавстві. Однак водночас необхідно підкреслити значимість історичних аспектів розвитку права, оскільки саме в історичних джерелах права, як правило, найбільш яскраво виражені міфологізовані елементи.

Розгляд правових міфів у правовій реальності передбачає виявлення ï історичних та ментальних коренів, які стали витоками сучасної правової системи України. У цьому контексті важливо не тільки показати міфологічні детермінанти історичних пам'яток права, котрі діяли на території України, a i продемонструвати відображення міфологізованих структур у так званому фольклорному праві.

Тут важливе значення має розмежування джерел і витоків права [9].

Слушною вважаємо думку, що джерелами права завжди є певні об'єктивовані юридичні тексти, а не факти юридичного життя. Джерело - це, передовсім, письмовий текст [13, с. 8]. Водночас, як справедливо зазначає P. Познер, основним витоком права $€$ так зване «практичне мислення». Останнє охоплює «анекдоти, самоаналіз, уяву, здоровий глузд, співпереживання, приписування мотивів, авторитет мовця, метафори, аналогії, звичаї, 


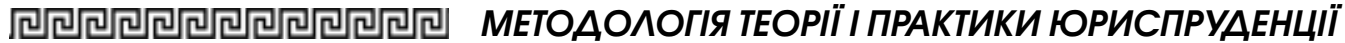

пам'ять, інтуїцію, очікування регулярностей» [12, с. 350-356].

Із цих позицій правові міфи можуть розглядатись як витоки права, котрі мають здебільшого усну форму, як мовні структури, застосовні в тих чи інших ситуаціях.

Констатуючи реальність взаємозв'язків моральних і правових інтенцій на численних прикладах фольклору, можна зробити висновок, що саме моральні витоки юридичних прислів їв і приказок є основоположними критеріями для формування природного, звичайного й навіть позитивного права. Можна стверджувати, що буденна мова володіє значним впливом на формування позитивного права і $є$ в певному сенсі джерелом права. Саме за допомогою мови громадяни, соціальні групи або суспільство загалом висловлюють своє бачення права, артикулюють вимоги щодо збільшення обсягу прав і намагаються «встановити» межі правового поля. Фактично в будьякому суспільстві складається своєрідний правовий, а також неправовий дискурс, який характеризує рівень наявної правосвідомості. Саме в юридичних прислів'ях знаходять відображення повчальні думки щодо окремих аспектів права, судоустрою, встановлення істини та справедливого судочинства.

Народна мудрість концентрує в собі історичний досвід переосмислення права, про що свідчать такі прислів'я: «Не поспішай карати, поспішай вислухати», «Шахрая помилувати - добро загубити», «Не за те вовка б'ють, що він сірий, а за те, що овечку з’їв, «Бережи порядок і порядок збереже тебе» [14, с. 135]. Використання прислів ’їв і приказок як певних «готових формул» поведінки, своєрідних заклинань, повторюваних у певних ситуаціях, наводить на думку, що ті міфологічні структури, які в них містяться, спрямовані також на конструювання реальності, а не тільки на іі відображення.

Такі смислоформи, котрі апелюють до фундаментальних правових ідей і створюють відповідний психологічний фон сприйняття тих чи інших ситуацій, можуть розглядатись як міфологічні витоки не тільки правосвідомості, але й позитивного права, оскільки прямий зв'язок між фольклором і позитивним правом не раз підкреслювався фахівцями у сфері юридичної етнології, антропологіï та лінгвістики [2; 262].

Міф як архаїчна форма права виступає першоджерелом права, містить у своїх архетипах нормативні начала. Крім того, міф є однією з форм існування права, оскільки окремі міфологеми проникають у нормативні тексти й містяться в юридичних джерелах та інших реаліях права як минулого, так і сьогодення. У цьому проявляється спадкоємність права.

Підтвердженням того, що правовий міф існував у різні історичні епохи, $€$ тексти Статуту Великого князівства Литовського - найважливішого джерела права феодальної Європи. Серед міфологічних основ Статутів Великого князівства Литовського - справедлива кара вогнем; категорія роду, родового; суду і правосуддя; поняття суду і правосуддя, судді, закону («писаного права») як синонімів правди і справедливості, необхідності судити «по праву писаному»; ідея договору [14].

Існування правових міфів, зумовлене особливостями правосвідомості, історичним обгрунтуванням у джерелах права, зв'язком права реального й бажаного дозволяє говорити про вплив правових міфів на правову систему, формування конкретних правових приписів. У цьому сенсі аналіз правових міфів повинен охоплювати їх дослідження в законодавчих текстах.

Правовий міф не наявний у законодавстві безпосередньо, але нерідко визначає його зміст шляхом конструювання певних схем миследіяльності.

Міфи позитивного права, як правило, відображають ті чи інші міфи правосвідомості, виражаючи їх у нормативній формі, які забезпечують необхідний зв'язок між правом і суспільною думкою про нього. У цьому сенсі міф не 
тільки виступає ідеологічним витоком права, а сам стає правовим регулятором, здійснюючи безпосередній правовий вплив на поведінку людини. Наприклад, страх перед відплатою (ще з часів архаїчного права і втілений у принципі «злочини повинні каратись») є не лише ідеологічною основою кримінального права, де отримує вираження в ідеі невідворотності покарання, а й виступає як фундаментальна міфологічна конструкція, яка створює образ права як інструмента відплати, сили, що має надіндивідуальне походження.

Позитивне право оперує значною кількістю міфів. Це міф про поділ права на приватне та публічне, про відображення в законі волі народу, про правову державу, про верховенство Конституції. Міфи знаходять своє вираження в окремих фактичних презумпціях, наприклад, у презумпції розумності людини, за якою вважається, що людина діє відповідно до раціональної оцінки ситуації [3, с. 89].

Міфологічне коріння мають нормативні положення про заборону втручання у приватне життя й недоторканість житла; положення про наклеп, закріплені в багатьох законодавчих актах різних правових систем; положення кримінального законодавства про встановлення відповідальності за осквернення могил; міфологічні елементи можна знайти і в нормах, які передбачають відповідальність за мародерство тощо. Наявність міфів у позитивному праві підвищує його легітимність, оскільки дозволяє звертатись до масового підсвідомого найбільш сталого елементу правосвідомості.

Міфологічні аспекті знаходять своє відображення у приписах правової поведінки. Місце правового міфу у структурі правової поведінці зумовлюються як суб'єктивними так і об'єктивними елементами. Більш значущим водночас виступає саме суб'єктивний аспект, оскільки він передбачає аналіз суб'єктивного боку складу як правомірного, так і протиправного діяння.
Правова поведінка не $є$ формою існування правових міфів, а виступає проявом їх існування у правовій свідомості. Серед детермінант правової поведінки мають бути не тільки раціональні, але й нераціональні начала, a, отже, і правовий міф. Правові міфи визначають загальну фундаментальну модель, грунтуючись на якій люди формують свою поведінку.

Міфологічні аспекти правової поведінки виявляються в декількох виміpax. По-перше, вони є самостійними елементами складу як правомірної, так i протиправної поведінки. По-друге, правові міфи використовуються для інтерпретації права 3 погляду осягнення добра і зла, права і неправа, для виявлення соціальних конотацій правової поведінки. По-третє, правові міфи детермінують правову поведінку через деформації правосвідомості.

Отже, у структурі правової реальності як особливої сфери людського буття правові міфи займають окреме місце. Існуючи в особливих формах, правові міфи трансформуються у правосвідомості, знаходять своє відображення у джерелах права, правових нормативах та у правовій поведінці.

Правовий міф займає особливе місие у ключових складниках правової реальності: правосвідомості, джерелах права, позитивному праві, правовій поведінці.

Правовий міф не може бути однозначно віднесений ані до раціональних, ані до ірраціональних елементів правосвідомості, існуючи як на буденному рівні, так $i$ у професійній правосвідомості. Водночас він здійснюе сильний вплив не тільки на індивідуальну, але й на колективну ü масову правосвідомість, існуе й на буденному рівні, й у професійній правосвідомості.

Виявлення історичних та ментальних коренів правових міфів дозволяе розглядати ї як витоки (першоджерела) сучасної правової системи України. Міфологізовані 


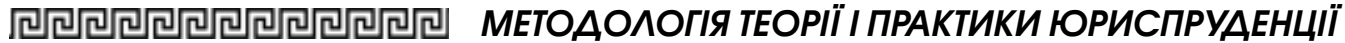

структури відображені ц̆ у історичних пам'ятках права, які діяли на території України (прикладом виступають Cтатути ВКЛ), ци $y$ фольклорному праві (юридичні прислів'я та інші міфологізовані усні мовні структури).

Розгляд правових міфів під кутом зору джерел права показує, щзо вони визначають становлення позитивного права, наповнення його конкретними нормативами.

Правові міфи властиві не тільки архайчному й литовсько-руському праву, але й сучасному українському законодавству. У сучасному праві міфи існують у вигляді симулякрів, тобто символів, які підміняють собою відсутню реальність.

у статmі доводиться, що наявність міфів у позитивному праві підвищуе його легітимність, оскільки дозволяе звертатись до масового підсвідомого - найбільш сталого елементу правосвідомості; виявленню місия правового міфу в механізмі детермінациї правової поведінки, а також з'ясуванню міфологічних аспектів юридичної кваліфікації правових учинків. Доводиться, щз правовий міф є особливим нераціональним елементом складу правового вчинку, спрямовуючи поведінку людини в певному напрямі.

Ключові слова: правові міфи, правова реальність, міфи буденної правосвідомості, міфи професійної правосвідомості, міфи у правовій культурі, міфи позитивного права, міфи у правовій поведінці.

Tishchenko J. Legal myth in the structure of legal reality

the article aims to clarify the place of the legal myth in the key components of legal reality: legal awareness, sources of law, positive law, legal leverage.

The legal myth cannot be unambiguously attributed to either rational or irrational elements of legal consciousness, existing both at the everyday level and in professional legal consciousness. At the same time, he has a strong influence not only on the individual, but also on the collective and mass legal consciousness, exists both at the everyday level and in the professional legal consciousness.

Identifying the historical and mental roots of legal myths allows us to consider them as the origins (primary sources) of the modern legal system of Ukraine. Mythologized structures are reflected both in historical monuments of law that operated on the territory of Ukraine (examples are the Statutes of the Grand Duchy of Lithuania) and in folklore law (legal proverbs and other mythologized oral language structures).

Consideration of legal myths from the point of view of sources of law shows that they determine the formation of positive law, filling it with specific regulations.

Legal myths are inherent not only in archaic and Lithuanian-Russian law, but also in modern Ukrainian law. In modern law, myths exist in the form of simulacra, that is symbols that replace the missing reality.

The article proves that the presence of myths in positive law increases its legitimacy, as it allows to address the mass subconscious - the most stable element of legal consciousness; identifying the place of legal myth in the mechanism of determination of legal behavior, as well as clarifying the mythological aspects of the legal qualification of legal acts. It is proved that the legal myth is a special irrational element of the legal act, directing human behavior in a certain direction.

Key words: legal myths, legal reality, myths of ordinary sense of justice, myths of professional sense of justice, myths of legal culture, myths of positive law, myths of legal behavior. 
Література:

1. Алексеев Н.Н. Основы философии права. Санкт-Петербург : Лань, 1999. 256 с.

2. Артикуиа Н.В. Мова права і юридична термінологія : навч. посіб. 2-ге вид., змін, $i$ доп. Київ : Стилос, 2004. 277 с.

3. Бондаренко Н.Л. О месте принципа добросовестности и разумности в системе приниипов гражданского права. Вестник Омского университета. Сер. : «Право». 2013. № 1. C. 89-93.

4. Велика українська юридична енциклопедія: у 20 m. T. 2 : Філософія права / редкол.: С.І. Максимов (голова) та ін.; Нац. акад. прав. наук України; Iн-т держави $i$ права імені В.М. Корецького НАН України; Нац. юрід. ун-т імені Ярослава Мудрого. Харків : Право, 2017. 1128 с.

5. Деррида Ж. Письмо и различие / пер. с фр. Д.Ю. Кралечкина. Москва : Академический проект, 2007. 495 c.

6. Деррида Ж. Трассирование и диффераниия. Философская и социологическая мыслль. 1995. № 5-6. С. 4-15.

7. Философия права : учебник для магистров / Г.И. Иконникова, В.П. Ляшенко. Москва : Юрайт, 2012. 364 с.

8. Максимов С.И. Правовая реальность : опыт философского осмысления : моногр. Харьков : Право, 2002. 328 с.

9. Марченко М.Н. Источники права. Москва : ТК Велби, Изд-во Проспект, 2008. $760 \mathrm{c.}$

10. Оборотов Ю.Н. Инфляция власти и права как индикаторы слабого государ- ства. Наукові праці Одеської національної юридичної академії. Одеса : Юрид. л.-ра, 2010. T. 9. C. 89-97.

11. Оборотов Ю.Н. Традиции и обновление в правовой сфере: вопросы теории (от познания к постижению права) : монография. Одесса : Юрид. л-ра, 2002. 280 с.

12. Познер Р. Проблеми юриспруденції ; пер. з англ. С. Савченка. Харків : Акта, 2004. 487 c.

13. Поляков А.В. Общая теория права. Феноменолого-коммуникативный подход : курс лекция. 2-е изд., доп. Санкт-Петербург : Юридический иентр Пресс, 2003. $845 \mathrm{c}$.

14. Статути Великого князівства Литовського: у 3-х томах. Том 1. Статут Великого князівства Литовського 1529 року / за ред. С.М. Ківалова, П.I. Музиченка, А.М. Панькова. Одеса: Юрид. л-ра, 2002. 464 c.

15. Тертишник B.М. Юридичні прислів'я - вказівні пальці юриспруденизї. Юридичний журнал. 2005. № 4(34). C. 134-135.

16. Цимбалюк М.м. Правосвідомість як об'єкт сучасного правознавства: методологічні альтернативи вивчення. Форум права.2011. № 4. С. 795-800.

17. Шелестов К.О. Домінуюче праворозуміння у функціонуванні правових систем : автореф. дис. на здобут. наук. ступ. канд. юрид. наук; спеи. : 12.00 .12 - філософія права. О., 2010. $20 \mathrm{c}$. 